International Journal of Life Sciences
Available online at www.sciencescholar.us
Vol. 4 No. 1, April 2020, pages: $109-117$
e-ISSN: 2550-6986, p-ISSN: $2550-6994$
https://doi.org/10.29332/ijls.v4n1.418

\title{
Sustainable Development Model of Subak in Denpasar City
}

\author{
(D) cosshatit \\ Putu Udayani Wijayanti a, Wayan Windia ${ }^{b}$, Dwi Putra Darmawan c, Widhianthini ${ }^{\mathrm{d}}$ \\ Manuscript submitted: 27 January 2020 Manuscript revised: 09 February 2020, Accepted for publication: 18 March 2020
}

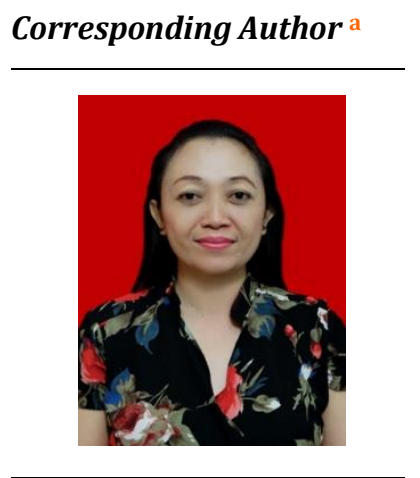

Keywords

agricultural knowledge;

farmer mindset;

subak;

sustainability model;

tri hita karana;

\begin{abstract}
Subak is a unique irrigation system in Bali that is based on Hinduism and the philosophy of tri hita karana that consists of elements of parhyangan, pawongan, and palemahan, are three balances and harmonies that are still maintained for sustainability. This study aims to identify changes in four dimensions of subak, which may threaten its sustainability in the city of Denpasar; identify the most sensitive dimension that influences the sustainability of subak in Denpasar; as well as formulate a development model of subak that will ensure its sustainability in Denpasar. Based on MDS analysis on the changes of different dimensions of subak that threaten its sustainability in Denpasar, it is known that the "dimension of mindset" is the most sensitive in processes of sustainability of subak. Sensitivity in this context relates to the awareness of the importance of farmer's mindset as a variable to ensure the sustainability of subak, considering the mindset of farmers will determine the success of sustainability processes on existing land management. Following that result, ISM analysis was done to formulate a development model for the sustainability of subak. Based on the analysis, the strongest driving factor that determines the realization of subak sustainability was obtained, namely the mindset of farmers. Farmer's mindset helps the protection of subak artifacts (ricefields) in terms of controlling the rate of agricultural land-use change beyond external efforts (such as through spatial regulation). Internal agreement between the members of subak through awig-awig is equally important in controlling agricultural land-use change. This is the consequence of the sustainability of subak.
\end{abstract}

International Journal of Life Sciences (c) 2020. This is an open access article under the CC BY-NC-ND license (https://creativecommons.org/licenses/by-nc-nd/4.0/).

a Udayana University, Denpasar, Indonesia

b Udayana University, Denpasar, Indonesia

c Udayana University, Denpasar, Indonesia

d Udayana University, Denpasar, Indonesia 


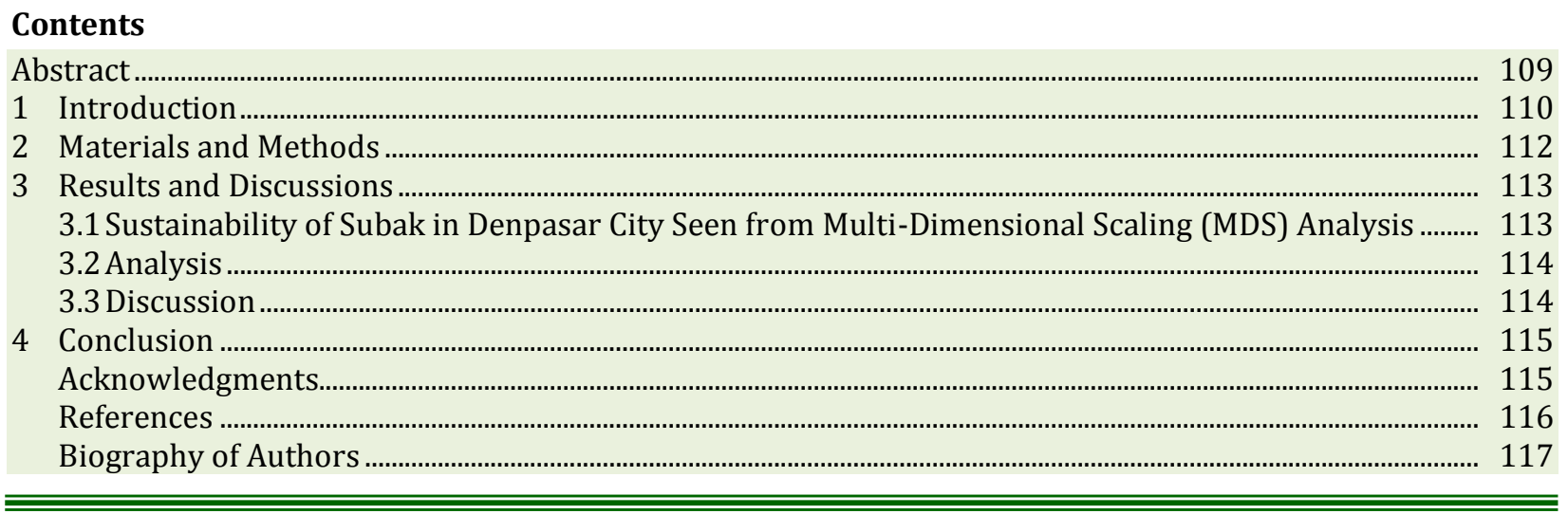

\section{Introduction}

Bali is the only province that maintains the continuity of subak institutions as reflected through the passing of Provincial Regulation No. 9 the Year 2012. There are a total of 1,604 subak and 1.107 subak abian that spread in both urban and rural areas (Bappeda Provinsi Bali, 2016). The provincial regulation on subak suggests that subak is a traditional organization of water management and/or cultivation management at the level of Balinese customary communities' farming system with socio-agricultural, religious, and economic aspects that historically grows and thrives (Sumiyati et al., 2017). Subak is a unique irrigation system in Bali is imbued by Hinduism, as many religious rituals are performed throughout different agricultural activities in subak. Subak is a socio-agricultural and religious organization is based on tri hita karana philosophy, namely three sources of balance and harmony, which consists of elements of parhyangan, pawongan dan palemahan (Arnawa, 2011; Hutasoit \& Wau, 2017; Parwati \& Trianasari, 2016).

Based on its originality, uniqueness, and values that have been globally accepted, which reflect human values as a whole and providing welfare for the society, The United Nations Educational, Scientific and Cultural Organization (UNESCO) considered subak as a cultural heritage in 2012 (Norken et al., 2017). The strength of subak as an irrigation system that is seasonally self-managed by farmers, especially for rice cultivation, is not only due to its function as water management organization and irrigation system but also related to food production, irrigated agricultural land ecosystem, and religious rituals that are related with rice cultivation (Aryawan et al., 2013). Subak also reflects honorable values that are universal and very relevant in the implementation of sustainable development.

Irrigated land with rice cultivation has an important economic role in the food supply, environmental preservation, biodiversity function, socio-cultural values conservation in rural areas and agricultural function in the tourism sector. Availability of water sources availability has been limited, however, the demand for water has increased over time. In the context of local wisdom, if ricefields are gone, the cultural practice of rice cultivation and its accompanying rituals will also vanish. Thus, it is important to preserve the subak system in Bali as the local genius of Bali. For that reason, ricefields must be preserved because without ricefields subak will not exist. According to Sutawan (2005), the concept of sustainability of subak includes the continuity of institutions, irrigation system, food production, ricefield ecosystem, tradition, and religious rituals that are related to rice cultivation, as well as the local natural environment that is the external factor of subak.

The challenges that are directly and indirectly faced by subak come from the tourism sector in Bali that has caused the younger generation to become less inclined to work in the agricultural sector. Tourism has brought several transformations in terms of income, transportation, and communication, which in the end triggered an exodus of the workforce to the tourism sector. The tourism sector in Bali that has thrived in the southern part of Bali has pushed urbanization exodus that is motivated by higher prestige for working in the tourism sector rather than farming.

The limitation of land-use change through spatial plans and regulations could oblige farmers to not sell their lands (Andersson \& D'Souza, 2014; Walder \& Kantelhardt, 2018). Ricefield areas in Denpasar has shrunk 230,6 hectares from 2018 to 2019. Based on that data, the current and previous ricefields that still exist in 
Denpasar in 2019 are about 1.939,4 hectares, meanwhile, the total ricefield areas in 2018 were up to 2.170 hectares. The shrinking of ricefields in 2018 from 2.170 hectares to $1.939,4$ hectares was caused by agricultural land-use change in Denpasar that has been unstoppable. The increase of population that live in Denpasar and the acceleration of economic growth have pushed out the existence of subak (BPS Kota Denpasar, 2019).

Land-use change and water problems related to competitive usage of water have become a serious threat to the sustainability of subak, especially in Denpasar, which has experienced the highest loss of ricefields. Thus, it is important to create a sustainable development model of subak in Denpasar.

\section{Literature review}

Subak

Subak is a rice farmer's organization that organizes traditional irrigation and has become part of Balinese culture. According to Provincial Regulation No. 9 the year 2012, subak is a traditional organization of water management and/or cultivation management at the level of Balinese customary communities' farming system with socio-agricultural, religious, and economic aspects that historically grows and thrives.

\section{Urban Agriculture}

According to the Rural-Urban Agriculture Foundation (RUAF) report in 2008, urban agriculture is a form of agricultural activity in or around urban areas. The most defining difference between urban and rural agriculture is the integration of urban agriculture with the urban economic system and urban ecosystem (Conforti \& Giampietro, 1997; Jackson, 2002; Yunlong \& Smit, 1994; Van Elsen, 2000).

\section{The concept of sustainability}

According to the Brundtland Commission report, what is meant by sustainability or preservation is an activity or effort to guarantee the needs of the present by considering the next generation in getting the same opportunity in meeting their needs. About subak, the preservation or sustainability of subak encompasses the efforts made to ensure the existence of subaks capable of carrying out their multi roles both economically, socially, culturally, and environmentally, both for the current generation and subsequent generations (Windia, 2008; Roth, 2014; Arta et al., 2020).

\section{System and model approach}

The system approach is a way of solving problems that begin with the identification of several needs so that it can produce the operation of the system that is considered effective. The systems approach is generally characterized by two things, namely: (1) finding all the important factors that exist to get a good solution to solve the problem and (2) making an element of quantitative models to help make decisions rationally.

The type of classification of the hypothetical model in this study is closer to the empirical model, where the hypothetical model that is formulated is based on data and suggestions or input from objective conditions in the field, namely stakeholders related to subak. Viewed from the aspect of its function, the model developed is classified as a predictive model, which is a model that shows what will happen if something happens.

\section{Rapid appraisal analysis}

The Subak RAP ordination technique is the development of RAP analysis developed by the University of British Columbia, through the Multi-Dimensional Scaling (MDS) method. MDS is a statistical technique that helps to transform into simpler dimensions, where this analysis is used to assess the sustainability of a system.

Wijayanti, P. U., Windia, W., Darmawan, D. P., \& Widhianthini, W. (2020). Sustainable development model of subak in Denpasar City. International Journal of Life Sciences, 4(1), 109-117. https://doi.org/10.29332/ijls.v4n1.418 


\section{Materials and Methods}

The selection of subaks as research locations is carried out in purposive technique, with the consideration that the region is a combination of urban and suburban areas that have experienced significant changes in the function of agricultural land. Based on these considerations, the selected subaks were: Anggak Subak, Umadesa Subak, and Umalayu Subak which are administratively located in Penatih Village, East Denpasar District, Denpasar City.

Key respondents in this study include three Pekaseh from each subak who were considered as representatives of farmer groups; two participants who were the Head of the Denpasar Agricultural Food and Horticultural Service Office and the Head of the Planning, Data, and Reporting Subdivision; two participants representing the National Land Agency (BPN) of Denpasar City; two participants representing the Denpasar City Public Works Department Employees in charge of urban spatial planning; two participants from NGOs in the environmental field; 5 community members living in the vicinity of the study site who are considered to be affected; and two academics.

Data collection techniques used in this study include in-depth interviews with various parties who have been determined as key respondents who are the object of research as well as documentation, which is a method of collecting secondary data obtained from related agencies to find a general description of the research area. This study uses a Multi-Dimensional Scaling (MDS) questionnaire in which some attributes are assessed by key respondents using scores and in-depth interviews conducted with experts about their understanding of the policies that need to be carried out in the context of sustainability of subak in Denpasar City. The statistical technique used in this study is the RAP Subak ordination technique through the MultiDimensional Scaling (MDS) method.

Table 1

The variables, dimensions, attributes, measurement scale, and scores in this study

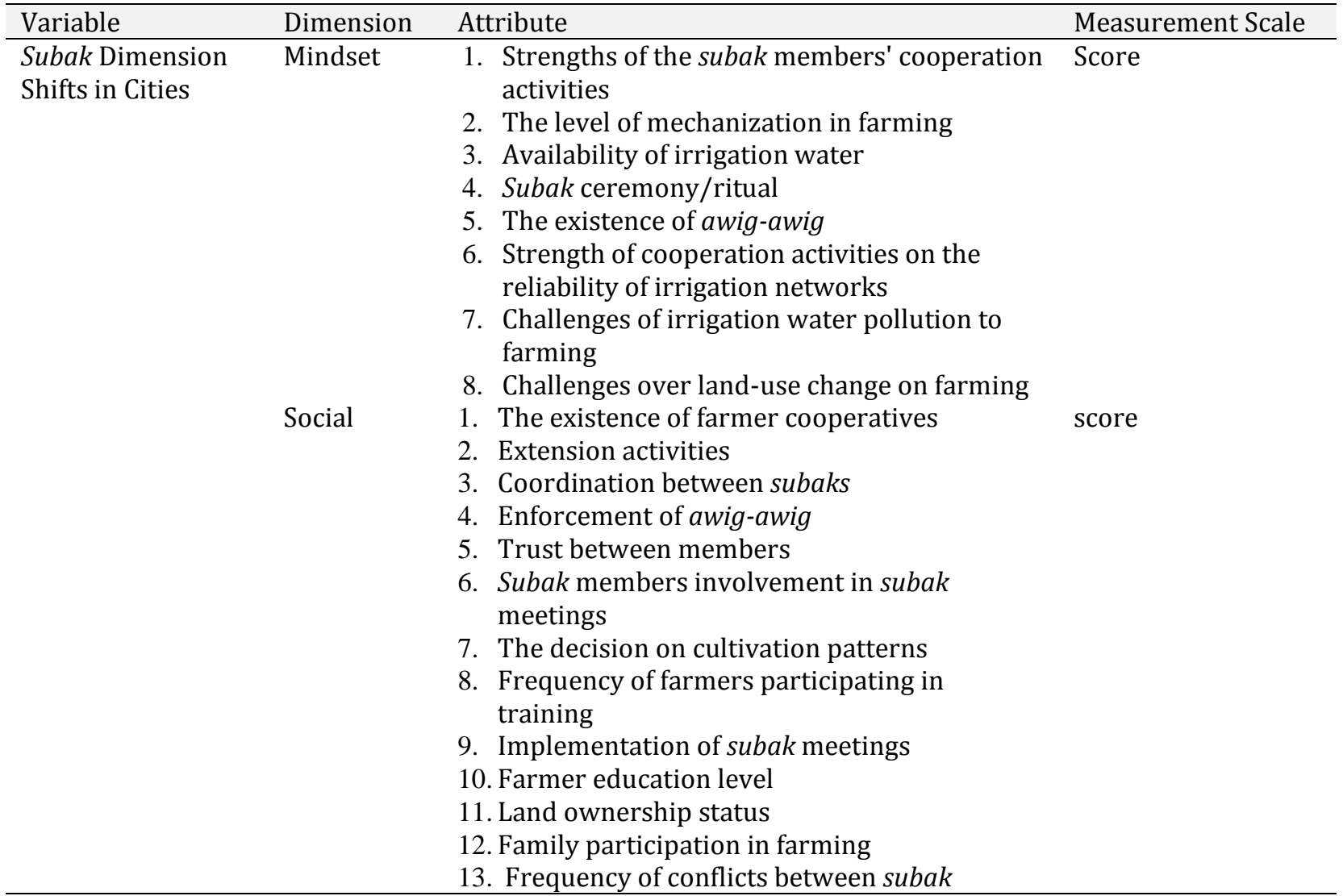




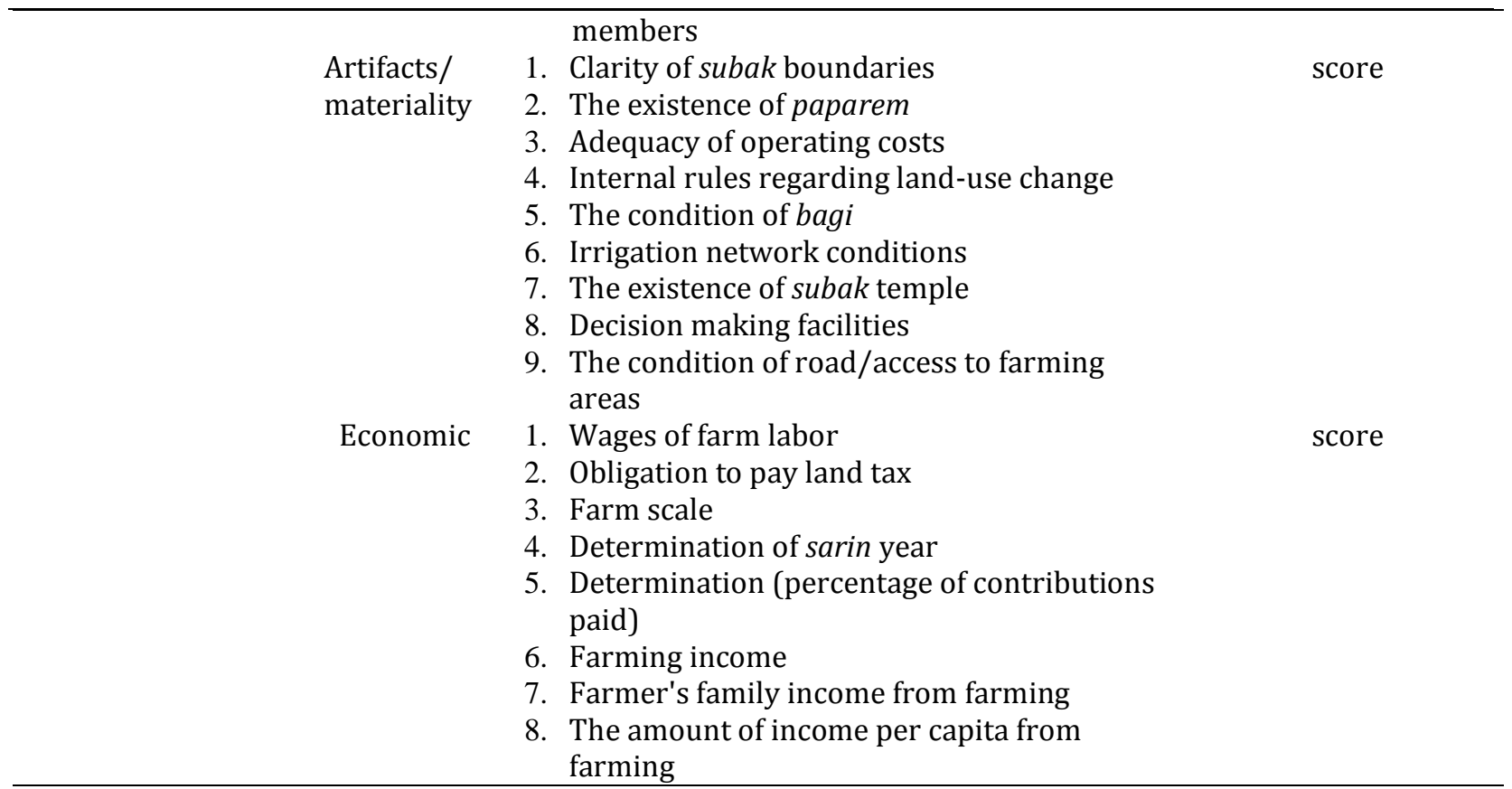

\section{Results and Discussions}

\subsection{Sustainability of Subak in Denpasar City Seen from Multi-Dimensional Scaling (MDS) Analysis}

The results of data processing with multi-dimensional scaling (MDS) show that the index value of the economic dimension of sustainability is 62.05. The value of the sustainability index of this economic dimension implies that the economic dimension in the development of a sustainable subak is in a sufficient category.

The results of leverage analysis on the economic dimension show that three indicators are sensitive to the value of the sustainability index of these dimensions, namely: (1) farm labor wages, (2) determination of sarin years, (3) farm scale. Wages of farm laborers must be a concern so that workers who work on farms can provide optimal results. If many workers feel they earn enough and could survive to work on farming, then the sustainability of the ricefields and also the main subaks will be maintained.

The results of the multi-dimensional scaling test show the value of the sustainability index on the social dimension is 82.13. This category of "very continuing" shows that the condition of subaks in Denpasar City still exists, although the number of subak functions has decreased. The decrease in the number of subaks and subak functions in Denpasar City has been caused by land-use change. Attributes that exist in the social dimension with the results of the leverage factor analysis show that the attribute of the frequency of farmers attending the training has the highest value (5.49), followed by the education level of the farmer (5.05) and determination of cultivation patterns (2.52).

The results of testing with multi-dimensional scaling (MDS) show that the most sensitive dimension in the results of this test is the mindset dimension, which is a value of 59.92. This means that mindset is the most sensitive dimension that has the most influence on the sustainability of subak. The mindset from the external aspect of Subak is a regional regulation created by the government to ensure that Subak remains sustainable by providing agricultural subsidies. The mindset of the internal aspects of Subak is the thinking of the farmers themselves to keep farming and not sell their land (not switching the function of agricultural land owned so far).

Based on the attributes that exist in the dimension of mindset with the value of the results of the leverage factor analysis, it is known that the attributes of the implementation of subak ceremonies/rituals have the

Wijayanti, P. U., Windia, W., Darmawan, D. P., \& Widhianthini, W. (2020). Sustainable development model of subak in Denpasar City. International Journal of Life Sciences, 4(1), 109-117. https://doi.org/10.29332/ijls.v4n1.418 
highest value (4.69), followed by the level of challenge of irrigation water pollution posed toward farming (3.60) and the strength of cooperation activities on the reliability of irrigation networks (3.04).

The results of the multi-dimensional scaling (MDS) test shows that the artifact/material dimension has a value of 94.87. This value is the highest value of all existing test dimensions. It means that physically or materially, everything is available to fulfill the needs in the effort to develop a sustainable subak. Then, based on the existing attributes on the artifact/material dimension, according to the value of the results of the leverage factor analysis, it is known that the operational and maintenance costs of the subak have the highest value (3.60), followed by the condition of the building (3.49) and the existence of a pararem with a value (3.27).

\subsection{Analysis}

The subak system sustainability development model in Denpasar is based on four dimensions, namely the economic, social, mindset and artifact dimensions. The four dimensions were tested with multi-dimensional scaling (MDS). The complete multi-dimensional scaling (MDS) results for the four dimensions are:

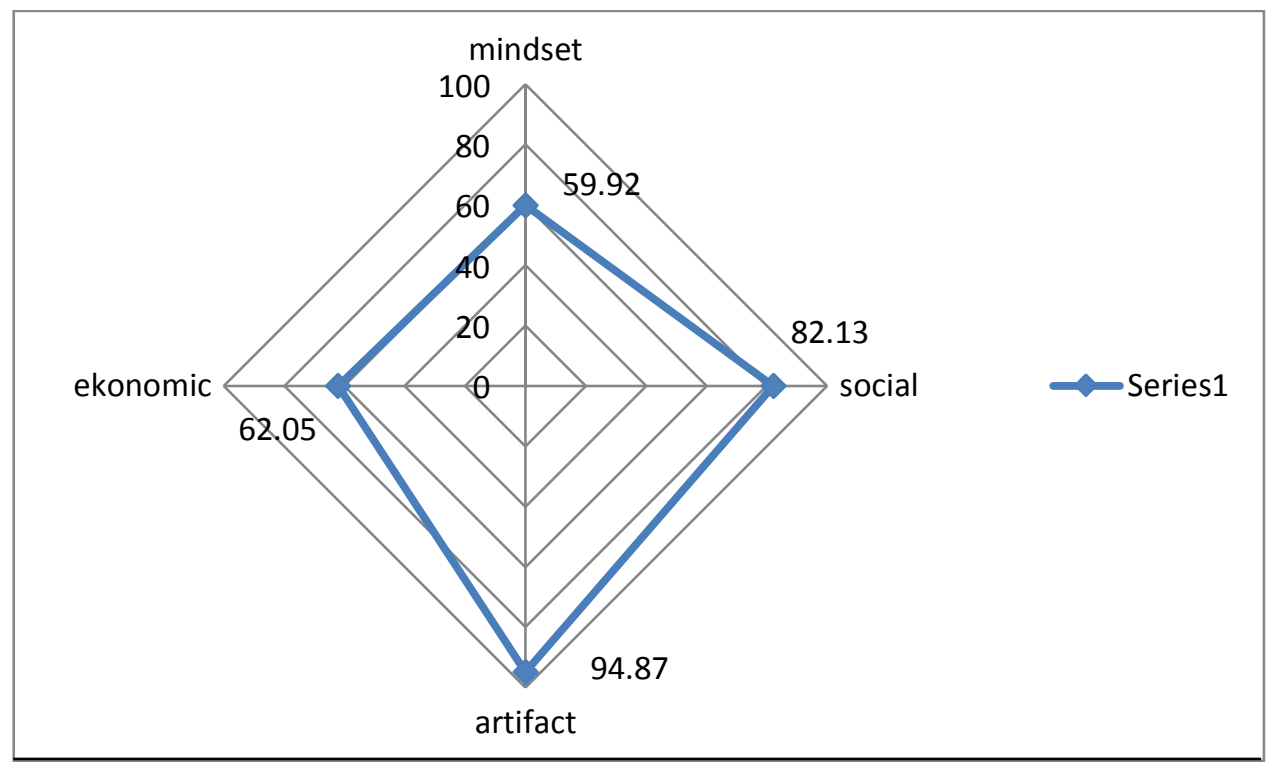

Figure 1. The complete multi-dimensional scaling (MDS) results

\subsection{Discussion}

To improve the development of sustainable subaks in the city of Denpasar (at least keeping existing subaks in existence) in the economic dimension, the wages of farm labor must be increased. If there is a decrease in the wages of farm labor, farmers' income will decrease. If farmers' incomes continue to decline, the younger generation will not be interested in working in the agricultural sector. This is likely to have an impact on the reduction in farming, causing a reduction in the number of subaks and subak functions in Denpasar.

Based on government records in the fourth quarter of 2019, the economy of Bali is expected to continue to grow strongly in the range of 5.10-5.50 percent. This growth is only supported by the improved performance of government consumption, investment and export performance abroad. This condition is also supported by an increase in the number of arrivals at Ngurah Rai Airport. From these data, the agricultural sector does not contribute much to the Balinese economy, therefore it is very important to pay more serious attention to farmers' efforts to increase regional income from the agricultural sector.

Based on data on the Balinese economy in the third quarter of 2019, growth in the fourth quarter of 2019 had been lower (slowing down) due to the limited household budget that had been used for the new school year and school holidays. Also, the dry season lasts drier and longer, which affected the end of the plantation 
harvest period. In the third quarter of 2019, the agricultural sector had little influence on the Balinese economy solely because of the dry season, not because of yields abundance, so the government still would have to side with farmers by continuing to innovate in government policies towards farmers.

Based on the results of the analysis of leverage factors on the social dimension, it can be seen that to improve the development of sustainable subak in Denpasar City, farmers must improve the quality of their agriculture through various kinds of training and improve their agricultural knowledge so that they can innovate in farming development (Abebe et al., 2013; Zheng et al., 2012; Blum, 1991). Sociologists believe that the key to progress in any field lies in changing the mindset or mindset of an issue. This aspect is one of the targets in maintaining agricultural sustainability, especially the subaks in Denpasar.

So that the development of sustainable subak in Denpasar that focuses on the dimension of mindset can be realized, the attributes of the implementation of subak ceremonies / rituals must be maintained and even must be improved. This can create a balance and harmony of the relationship between humans and God, between humans and others, and between humans and their environment, following the philosophy of tri hita karana. If there is a decrease in the attributes of the implementation of subak ceremonies / rituals, then the quality of the land may decrease, the quality of the environment and the existenseof farmers will also continue to be threatened.

If the govenrment of Denpasar intends to maintain sustainable subak development and improve the artifact/material dimensions, the adequacy of operational costs and subak maintenance attributes must be improved. If there is a decrease in this attribute, the quality and presence of farmers will be negatively affected. If the quality of farmers from the artifact / material dimension decreases, then indirectly the existence of farmers to manage agriculture will also decrease. This happens because the belief in the development of subak in Bali, which is based on the philosophy of tri hita karana is no longer maintained in balance.

\section{Conclusion}

Mindset is a belief that influences one's attitude and behavior. Those who have a negative mindset will behave negatively, and vice versa. Awareness of the importance of changing mindsets for farmers will affect the success in managing land owned, because without accompanied by changes in mindset, the chances of farmers to succeed are very small. Various learning processes that change the mindset may be said to be a provision for farmers to be empowered.

In the case of sustainable subak development, it seems that there is no mindset on the part of policy makers that supports the sustainability of the existence of subak and the agricultural sector in general. Based on BPS data in 2010 it is known that the conversion of paddy fields in the 2005-2009 period averaged more than $1000 \mathrm{ha}$ /year. Based on these data, it seems that strict implementation of spatial planning (following applicable law) is necessary, namely by determining the number of fields that must remain in Bali (permanent fields) which are explained in detail in each district/city in Bali. Furthermore, the number of rice fields (minimum) that should exist in each region must also be determined, subaks are given adequate subsidies and protection so that subaks can provide the best benefits for farmers (Windia, 2013).

Based on the results of testing with multi-dimensional scaling (MDS) the most sensitive dimension in the results of this test is the mindset dimension, which is at the value of 59.92. This is the smallest value, so it is a very sensitive dimension value. This means that when the mindset of policymakers in reducing land-use change is not optimal, the sustainability of subak in Denpasar City will be impacted. Similarly in the case of the internal mindset of farmers, if farmers feel that the land they are working on does not provide optimal results, farmers will tend to sell or rent out agricultural land to provide results that suit their families' needs.

On the other hand, if the owners of agricultural lands still maintain their agricultural land, of course, the existence of subaks can still be maintained. Therefore, internal factors and external factors in the development of sustainable subaks must cooperate, so that the desire of farmers and the government to continue to maintain subaks as water providers for irrigation could be achieved.

\section{Acknowledgments}

We are grateful to two anonymous reviewers for their valuable comments on the earlier version of this paper.

Wijayanti, P. U., Windia, W., Darmawan, D. P., \& Widhianthini, W. (2020). Sustainable development model of subak in Denpasar City. International Journal of Life Sciences, 4(1), 109-117. 


\section{References}

Abebe, G. K., Bijman, J., Pascucci, S., \& Omta, O. (2013). Adoption of improved potato varieties in Ethiopia: The role of agricultural knowledge and innovation system and smallholder farmers' quality assessment. Agricultural Systems, 122, 22-32. https://doi.org/10.1016/j.agsy.2013.07.008

Andersson, J. A., \& D'Souza, S. (2014). From adoption claims to understanding farmers and contexts: A literature review of Conservation Agriculture (CA) adoption among smallholder farmers in southern Africa. Agriculture, Ecosystems \& Environment, 187, 116-132. https://doi.org/10.1016/j.agee.2013.08.008

Arnawa, I. K. (2011). Kajian tentang Pelestarian Subak Ditinjau dari Aktivitasnya yang Berlandaskan Konsep Tri Hita Karana. Jurnal Agrimeta, 1(01).

Arta, I. K. G., Suda, I. K., \& Dharmika, I. B. (2020). Cultural shifting on agricultural Subak Abian in Jembrana Regency. International Journal of Linguistics, Literature and Culture, 6(2), 47-58. https://doi.org/10.21744/ijllc.v6n2.870

Aryawan, I. P. S., Windia, W., \& Wijayanti, P. U. (2013). Peranan Subak dalam Aktivitas Pertanian Padi Sawah (Kasus di Subak Dalem, Kecamatan Kerambitan, Kabupaten Tabanan). Jurnal Agribisnis dan Agrowisata (Journal of Agribusiness and Agritourism).

Blum, A. (1991). What can be learned from a comparison of two agricultural knowledge systems? The case of The Netherlands and Israel. Agriculture, ecosystems \& environment, 33(4), 325-339. https://doi.org/10.1016/0167-8809(91)90055-3

BPS Provinsi Bali. 2019. Bali dalam Angka 2018.

Conforti, P., \& Giampietro, M. (1997). Fossil energy use in agriculture: an international comparison. Agriculture, ecosystems \& environment, 65(3), 231-243. https://doi.org/10.1016/S01678809(97)00048-0

Hutasoit, H., \& Wau, R. (2017). Menuju Sustainability dengan Tri Hita Karana (Sebuah Studi Interpretif Pada Masyarakat Bali). Business Management Journal, 13(2).

Jackson, W. (2002). Natural systems agriculture: a truly radical alternative. Agriculture, ecosystems \& environment, 88(2), 111-117. https://doi.org/10.1016/S0167-8809(01)00247-X

Norken, I. N., Suputra, I. K., Arsana, I. G. N. K., \& Ngurah, I. G. (2017). Institutional and Regulatory Roles in Maintaining Sustainability of Subak as a World Cultural Heritage in Bali. Asian Agri-History, 21(4), 245-254.

Parwati, N. N., \& Trianasari, T. (2016). Educational Tourism Based on Tri Hita Karana in Mengesta in Bali. Binus Business Review, 7(3), 307-314. https://doi.org/10.21512/bbr.v7i3.1815

Roth, D. (2014). Environmental sustainability and legal plurality in irrigation: the Balinese subak. Current Opinion in Environmental Sustainability, 11, 1-9. https://doi.org/10.1016/j.cosust.2014.09.011

Sumiyati, Windia, I. W., \& Tika, I. W. (2017). Operasional dan pemeliharaan jaringan irigasi subak di Kabupaten Tabanan.Jurnal Kajian Bali (Journal of Bali Studies), 7(1), 121-138. https://doi.org/10.24843/JKB.2017.v07.i01.p08

Sutawan, N. S. Pusposutardjo, W Windia, I G Suyatna, W. Sudarta, W. Arga, W. Widyantara, K Suamba, G. Sedana, I M. Sarjana, N.W. Sri Astiti, IGA Oka. Suryawardani, I G. Pitana, I GAA Ambarawati. (2005). Revitalisasi Subak dalam Memasuki Era Globalisasi. Editor I Gede Pitana dan I Gede Setiawan AP. Yogyakarta: Penerbit Andi.

van Elsen, T. (2000). Species diversity as a task for organic agriculture in Europe. Agriculture, ecosystems \& environment, 77(1-2), 101-109. https://doi.org/10.1016/S0167-8809(99)00096-1

Walder, P., \& Kantelhardt, J. (2018). The environmental behaviour of farmers-capturing the diversity of perspectives with a Q methodological approach. Ecological Economics, 143, 55-63. https://doi.org/10.1016/j.ecolecon.2017.06.018

Windia, W. (2008). Menuju Sistem Irigasi Subak yang Berkelanjutan di Bali. Orasi Ilmiah. Disampaikan dalam pidato pengukuhan jabatan guru besar dalam bidang ilmu sosial ekonomi pertanian pada Fakultas Pertanian Universitas Udayana tanggal, 29.

Yunlong, C., \& Smit, B. (1994). Sustainability in agriculture: a general review. Agriculture, ecosystems \& environment, 49(3), 299-307. https://doi.org/10.1016/0167-8809(94)90059-0

Zheng, Y. L., He, Q. Y., Ping, Q. I. A. N., \& Ze, L. I. (2012). Construction of the ontology-based agricultural knowledge management system. Journal of Integrative Agriculture, 11(5), 700-709. https://doi.org/10.1016/S2095-3119(12)60059-8 


\section{Biography of Authors}

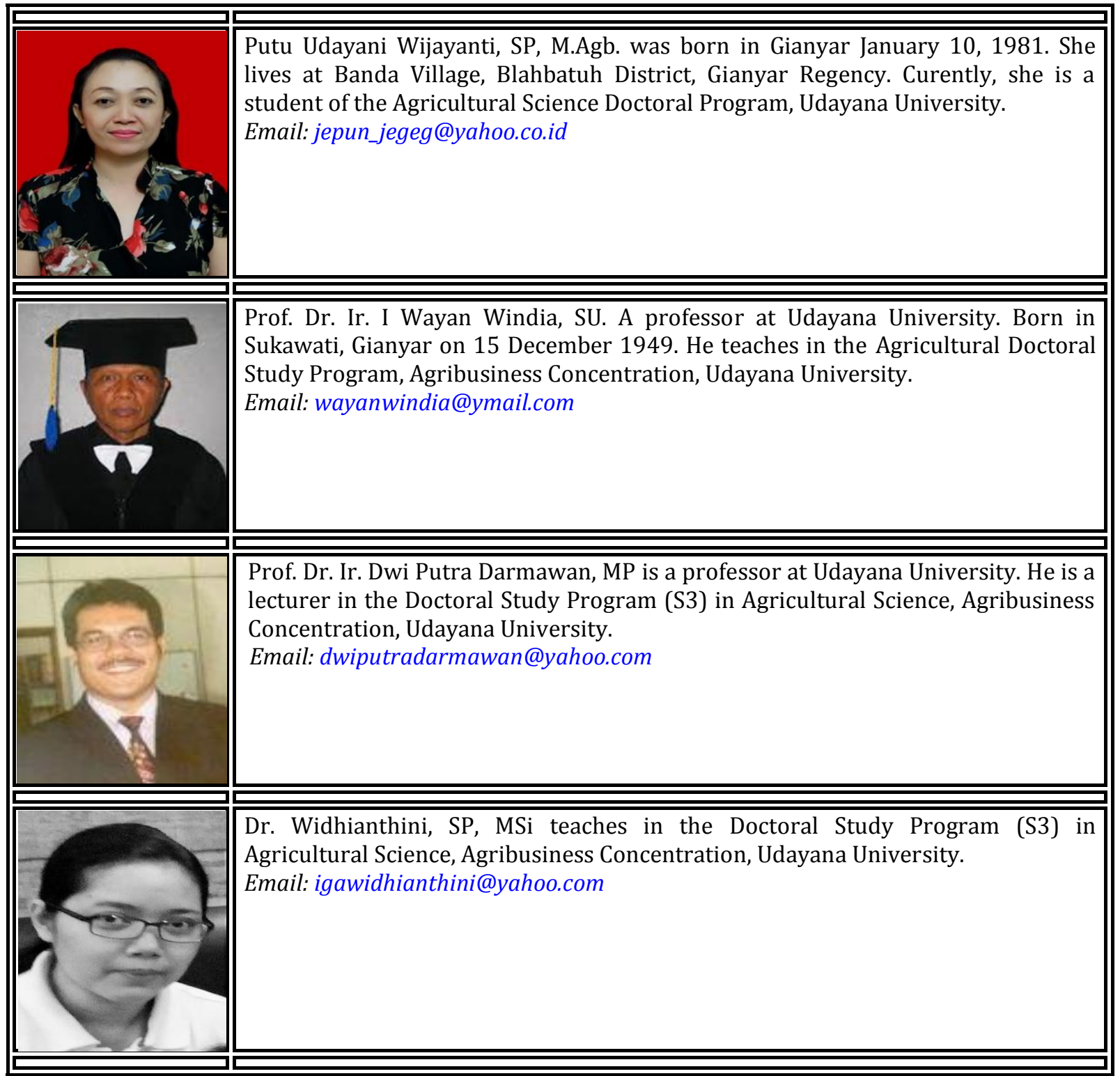

Wijayanti, P. U., Windia, W., Darmawan, D. P., \& Widhianthini, W. (2020). Sustainable development model of subak in Denpasar City. International Journal of Life Sciences, 4(1), 109-117. https://doi.org/10.29332/ijls.v4n1.418 